\title{
DESAIN POLA PARKIR SEPEDA MOTOR DENGAN PENDEKATAN ERGONOMI PARTISIPATORI
}

\author{
Bambang Suhardi ${ }^{1}$, Pringgo Widyo Laksono ${ }^{2}$, dan Akbar Aditya Nugraha ${ }^{3}$ \\ 1,2 Staff Pengajar Program Studi Teknik Industri, Fakultas Teknik, Universitas Sebelas Maret \\ ${ }^{3}$ Mahasiswa Program Studi Teknik Industri, Fakultas Teknik, Universitas Sebelas Maret \\ J1. Ir. Sutami No. 36A Kentingan Surakarta, 57126
}

\begin{abstract}
Motorcycle parking area in the Faculty of Engineering UNS is $2895 \mathrm{~m}^{2}$ which is divided into 5 sectors. Problems arising in the parking lot as follows: irregular parking position, the distance between motorcycles too close, the user is difficult to remove a motorcycle, and motorcycles parked carelessly in the parking circulation path. To overcome this problem parking needs to be designed parking pattern using participatory ergonomic approach. The results showed that the optimal parking pattern in terms of capacity is a parking pattern with $90^{\circ}$ angles. Parking patterns with $90^{\circ}$ angle can accommodate 1046 motorcycles.
\end{abstract}

Keywords: design, participatory ergonomics, parking facilities, parking patterns.

\section{PENDAHULUAN}

Fasilitas parkir di perguruan tinggi memiliki peran penting untuk memenuhi kebutuhan warga perguruan tinggi yang menggunakan kendaraan pribadi akibat dari tingginya tingkat mobilitas. Fasilitas parkir pada dasarnya adalah lokasi yang ditentukan sebagai tempat pemberhentian kendaraan yang tidak bersifat sementara untuk melakukan kegiatan pada suatu kurun waktu (Keputusan Direktur Jenderal Perhubungan Darat tentang Pedoman Teknis Penyelenggaraan Fasilitas Parkir, 1996).

Permasalahan parkir sepeda motor di Fakultas Teknik Universitas Sebelas Maret (FT. UNS) sebagai berikut: posisi parkir kendaraan ada yang tidak teratur sehingga berakibat pengguna parkir lain kesulitan dalam memarkir kendaraannya, jarak antar kendaraan yang parkir terlalu dekat sehingga mengakibatkan terjadinya benturan antar kendaraan yang parkir dan kesulitan pengguna parkir dalam mengeluarkan kendaraannya serta terdapat kendaraan yang diparkir secara sembarangan di jalur sirkulasi parkir sehingga mengganggu kendaraan lain yang akan lewat. Permasalahan parkir di FT UNS akan diselesaikan dengan menggunakan metode ergonomi partisipatori.

Wilson \& Heines (dalam Theberge, 2006) menyatakan bahwa ergonomi partisipatori adalah keterlibatan individu dalam perencanaan dan pengawasan terhadap aktivitas kerjanya sendiri. Pendekatan ergonomi partisipatori adalah keterlibatan langsung dari seluruh stakeholder dalam perencanaan dan pelaksanaan tugas-tugas mereka (Cole dkk, 2000; de Jong \& Vink, 2002).

Dinta (2005) melakukan penelitian mengenai pola parkir yang optimal di Pasar Klewer. Kondisi pola parkir di Pasar Klewer tidak berbeda jauh dengan pola parkir di FT UNS. Pemecahan masalah dengan menggunakan pendekatan ergonomi partisipatori. Penelitian lain yang terkait dengan ergonomi partisipatori dilakukan Aziz (2011). Pendekatan ergonomi partisipatori digunakan untuk merancang ulang stasiun kerja untuk operator general part dan divisi stamping tools pada PT. Mekar Armada Jaya, Magelang.

\footnotetext{
${ }^{*}$ Correspondance : bshardi@plasa.com
} 


\section{METODE PENELITIAN}

Obyek penelitian

Obyek dari penelitian ini adalah tempat parkir FT UNS.

Metode pengumpulan data

Metode yang digunakan dalam pengumpulan data ialah dengan cara wawancara terhadap stakeholder (mahasiswa dan penjaga parkir) atas keluhan-keluhan mereka terhadap kondisi tempat parkir di FT UNS.

Tahapan penelitian

Tahap 1. Melakukan observasi langsung terhadap penerapan delapan aspek ergonomi di tempat parkir FT UNS. Tahap ini ditujukan untuk mencari masalah krusial yang perlu dipecahkan.

Tahap 2. Tahap ini dilakukan proses partisipatori melalui wawancara dan dilanjutkan dengan focus grup discussion kepada stakeholders. Langkah-langkah yang dilakukan sebagai berikut:

a. Identifikasi keluhan

Pada tahap ini mahasiswa dan penjaga parkir diwawancarai mengenai keluhan yang dirasakan terhadap kondisi tempat parkir terkait dengan delapan aspek ergonomi.

b. Meminta saran kepada tim ergonomi partisipatori

Untuk melakukan pemecahan masalah ergonomi yang berhubungan dengan tempat parkir, saran dimintai berdasarkan keahlian masing-masing

c. Rancangan perbaikan

Pada tahapan ini stakeholders dimintai tanggapan untuk menentukan desain pola parkir. Tanggapan stakeholders digunakan sebagai acuan dalam merancang desain pola parkir sehingga kebutuhan dari stakeholders dapat terpenuhi.

d. Pembuatan pola parkir

Langkah dalam pembuatan pola parkir diawali dengan cara menentukan satuan ruang parkir (SRP). SRP merupakan ukuran kebutuhan ruang untuk parkir suatu kendaraan dengan nyaman dan aman dengan besaran ruang yang seefisien mungkin. SRP ditentukan dengan melihat ukuran dimensi kendaraan kemudian disesuaikan dengan penambahan atau allowance. Langkah berikutnya adalah merancang desain pola parkir. Desain pola parkir dibuat dengan mengacu pada Keputusan Direktur Jenderal Perhubungan Darat tentang Pedoman Teknis Penyelenggaraan Fasilitas Parkir tahun 1996, yang menentukan pola parkir berdasarkan sudut-sudut antara lain $30^{\circ}, 45^{\circ}, 60^{\circ}$, maupun $90^{\circ}$. Langkah terakhir adalah menghitung kapasitas maksimal dari desain pola parkir yang telah dibuat.

\section{HASIL DAN PEMBAHASAN}

\section{Penentuan pola parker optimal}

Rancangan desain pola parkir yang ajukan dalam penelitian ini adalah pola parkir dengan sudut $30^{\circ}, 45^{\circ}, 60^{\circ}$, dan $90^{\circ}$ sebagaimana Pedoman Teknis Penyelenggaraan Fasilitas Parkir tahun 1996. Penerapan perancangan desain sudut pola parkir dilakukan untuk mendapatkan daya tampung petak parkir paling optimal. Permasalahan yang diperoleh dari wawancara ergonomi partisipatori, diketahui permasalahan pola parkir di Fasilitas Parkir FT UNS adalah 1) penataan parkir yang kurang tertib, 2) pengguna tidak mau mengisi area parkir yang jauh sehingga terjadi penumpukan kendaraan di suatu sektor parkir, 3) jalur sirkulasi parkir sepeda motor yang sempit, 4) pengaturan beberapa sepeda motor tidak teratur, 5) Pengguna sering mengkhawatirkan terjadinya sepeda motor rubuh dan helm terjatuh. Dominasi harapan pengguna adalah pembenahan pengaturan parkir, rambu penunjuk arah sirkulasi parkir serta 
pola parkir beserta satuan ruang parkir di masing-masing sektor fasilitas parkir sepeda motor FT UNS.

\section{Perancangan Desain Pola Parkir di Fasilitas Parkir FT UNS Sektor 1}

Perancangan desain pola parkir yang diajukan agar didapatkan desain pola parkir yang paling optimal untuk keadaan fasilitas parkir sepeda motor FT UNS sektor I adalah.

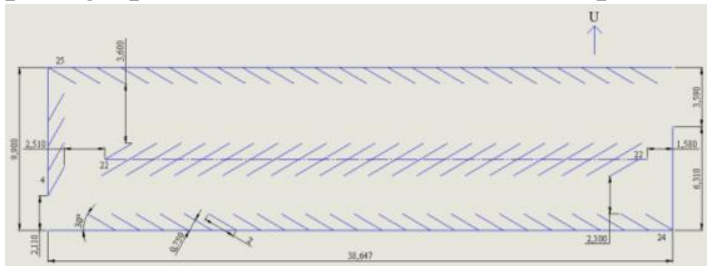

(a)

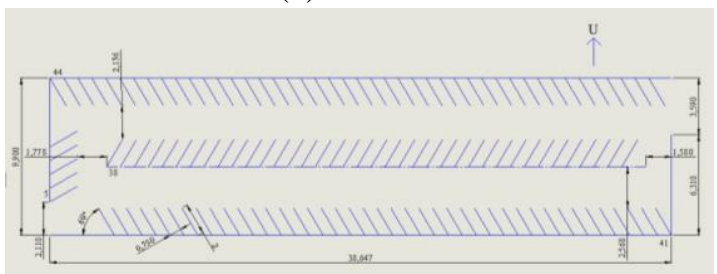

(c)

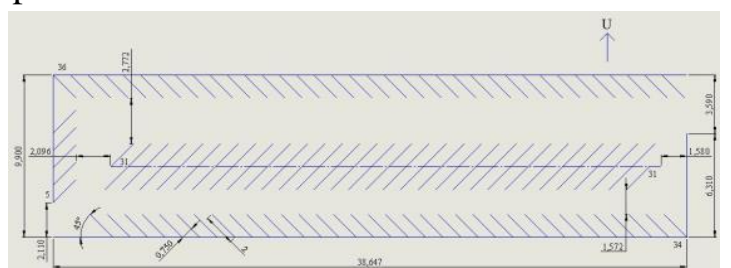

(b)

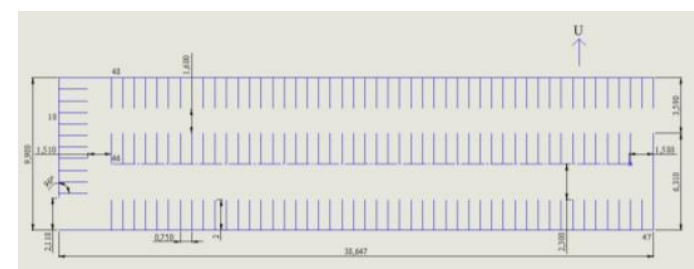

(d)

Gambar 1. Desain Pola Parkir Fasilitas Parkir FT UNS Sektor 1 menggunakan pola parkir dengan sudut (a) $30^{\circ}$, (b) $45^{\circ}$, (c) $60^{\circ}$ dan (d) $90^{\circ}$ (dalam meter)

Pada rancangan Gambar 1, pada pola parkir (a) $30^{\circ}$, (b) $45^{\circ}$, (c) $60^{\circ}$ dan (d) $90^{\circ}$, pengguna dari arah masuk fasilitas parkir dapat parkir secara langsung sesuai dengan pembagian area parkir yang telah disediakan. Pada sudut pola parkir $30^{\circ}, 45^{\circ}, 60^{\circ}$, dan $90^{\circ}$, posisi parkir sepeda motor memperluas jalan masuk sepeda motor, yakni lebih dari $1,5 \mathrm{~m}$, dan lebar ruas tersebut masih memenuhi standar minimal jalur sirkulasi sebesar 1.5 meter. Hal ini membantu mengatasi permasalahan jalur sirkulasi parkir sepeda motor yang sempit. Pemetaan satuan ruang parkir dengan sudut pola parkir $30^{\circ}, 45^{\circ}, 60^{\circ}$, dan $90^{\circ}$, membantu mengatasi permasalahan penataan parkir yang kurang tertib, pengaturan beberapa sepeda motor tidak teratur. Rancangan sudut pola parkir $30^{\circ}, 45^{\circ}, 60^{\circ}$, dan $90^{\circ}$ memiliki lebar satuan ruang parkir 0.75 meter. Lebar satuan ruang parkir 0.75 meter mengurangi kekhawatiran pengguna atas terjadinya sepeda motor rubuh dan helm terjatuh. Rancangan sudut pola parkir $30^{\circ}, 45^{\circ}, 60^{\circ}$, dan $90^{\circ}$ pada bentuk parkir sektor 1, memiliki daya tampung maksimal 151 ruang satuan parkir.

\section{Perancangan Desain Pola Parkir Sektor 2}

Setiap sektor pada fasilitas parkir sepeda motor FT UNS memiliki dimensi dan bentuk yang berbeda. Pada Gambar 5.17, 4.18, 4.19, 4.20 ditunjukkan beberapa desain pola parkir dengan berbagai sudut yang sesuai dengan keadaan dari fasilitas parkir sepeda motor FT UNS pada sektor 2. Desain tersebut juga disertai dengan arah sirkulasi parkir sebagai dasar perancangan arah sudut pola parkir. Dari beberapa desain pola parkir tersebut akan didapatkan desain pola parkir yang paling optimal untuk keadaan fasilitas parkir sepeda motor FT UNS sektor 2. 


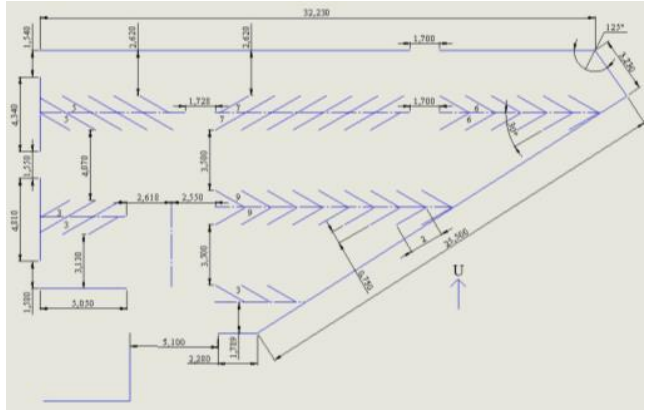

(a)

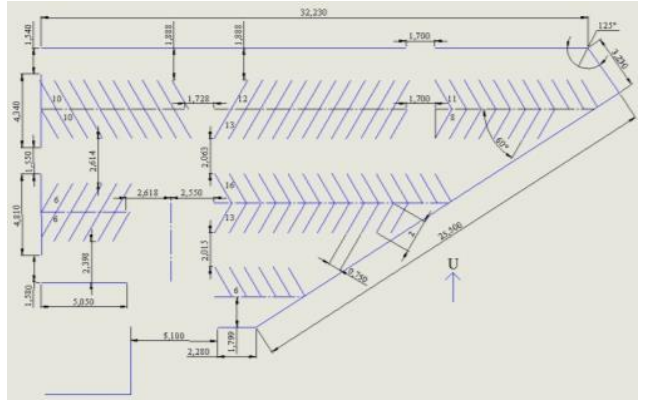

(c)

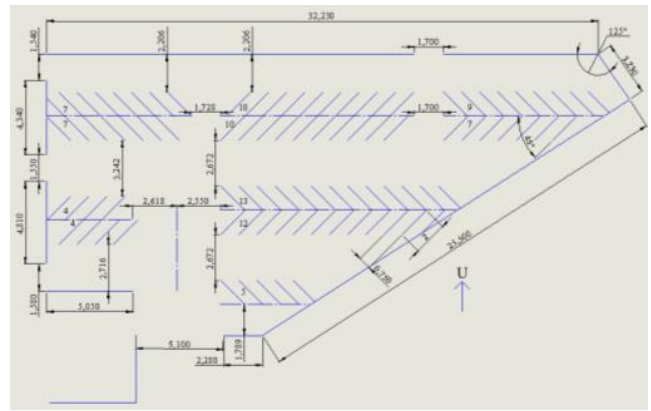

(b)

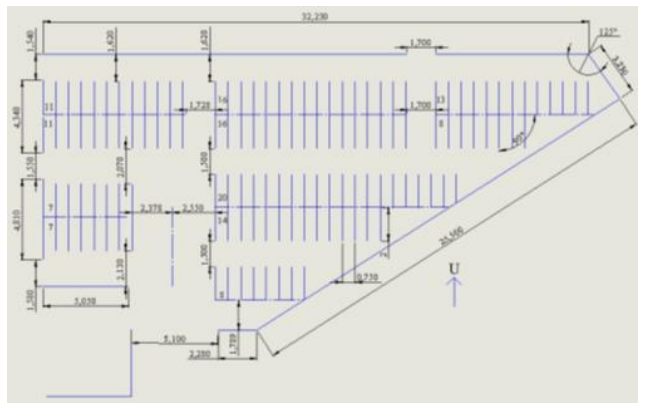

(d)

Gambar 2. Desain Pola Parkir Fasilitas Parkir FT UNS Sektor 2 menggunakan pola parkir dengan sudut (a) $30^{\circ}$, (b) $45^{\circ}$, (c) $60^{\circ}$ dan (d) $90^{\circ}$ (dalam meter)

Pada sudut pola parkir (a) $30^{\circ}$, (b) $45^{\circ}$, (c) $60^{\circ}$ dan (d) $90^{\circ}$, posisi parkir sepeda motor tidak mengganggu luas jalan masuk sepeda motor, yakni lebih dari 1.5 meter, dan lebar ruas tersebut masih memenuhi standar minimal jalur sirkulasi sebesar 1.5 meter. Hal ini membantu mengatasi permasalahan jalur sirkulasi parkir sepeda motor yang sempit. Pemetaan satuan ruang parkir dengan sudut pola parkir $30^{\circ}, 45^{\circ}, 60^{\circ}$ dan $90^{\circ}$, membantu mengatasi permasalahan penataan parkir yang kurang tertib, pengaturan beberapa sepeda motor tidak teratur. Rancangan sudut pola parkir $45^{\circ}$ memiliki lebar satuan ruang parkir 0.75 meter. Lebar satuan ruang parkir 0.75 meter mengurangi kekhawatiran pengguna atas terjadinya sepeda motor rubuh dan helm terjatuh. Rancangan sudut pola parkir $30^{\circ}, 45^{\circ}, 60^{\circ}$ dan $90^{\circ}$, pada bentuk parkir sektor 2 , memiliki daya tampung maksimal 131 ruang satuan parkir.

\section{Perancangan Desain Pola Parkir Sektor 3}

Setiap sektor pada fasilitas parkir sepeda motor FT UNS memiliki dimensi dan bentuk yang berbeda. Pada Gambar 5.20, 4.21, 4.22, 4.23 disajikan desain pola parkir dengan berbagai sudut yang sesuai dengan keadaan dari fasilitas parkir sepeda motor FT UNS pada sektor 3 . Desain tersebut juga disertai dengan arah sirkulasi parkir sebagai dasar perancangan arah sudut pola parkir. Dari beberapa desain pola parkir tersebut akan didapatkan desain pola parkir yang paling optimal untuk keadaan fasilitas parkir sepeda motor FT UNS sektor 3.

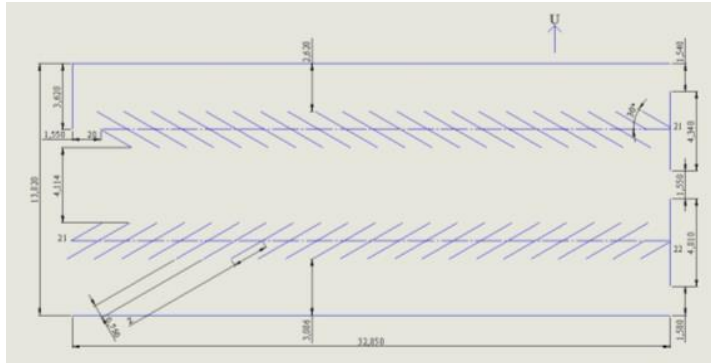

(a)

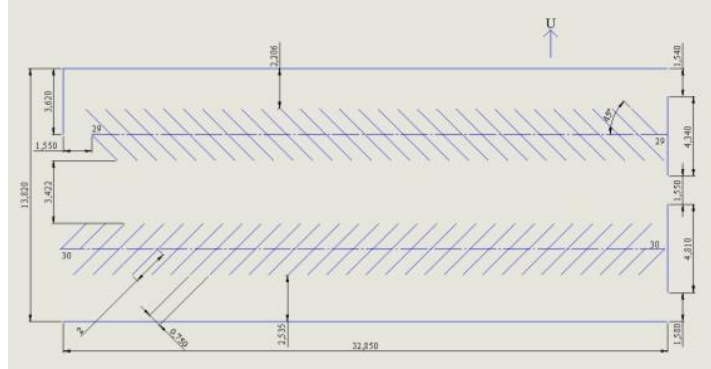

(b) 


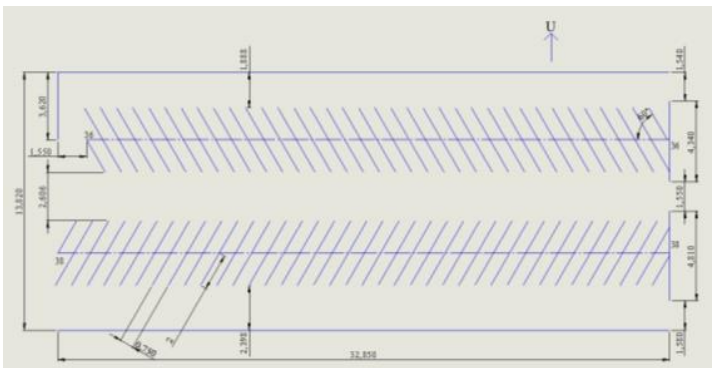

(c)

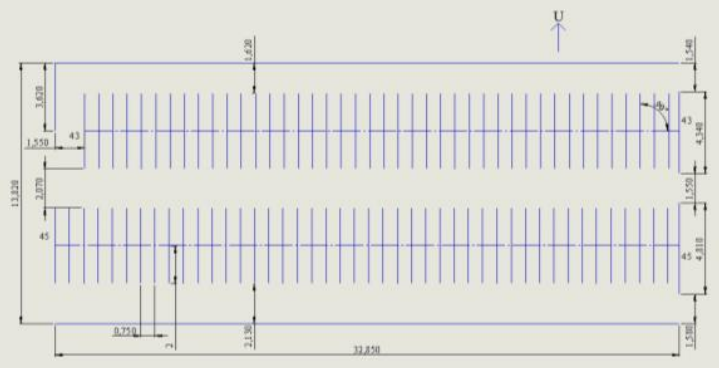

(d)

Gambar 3. Desain Pola Parkir Fasilitas Parkir FT UNS Sektor 3 menggunakan pola parkir dengan sudut (a) $30^{\circ}$, (b) $45^{\circ}$, (c) $60^{\circ}$ dan (d) $90^{\circ}$ (dalam meter)

Pada sudut pola parkir $30^{\circ}, 45^{\circ}, 60^{\circ}$ dan $90^{\circ}$, posisi parkir sepeda motor tidak mengganggu luas jalan masuk sepeda motor, yakni lebih dari 1.5 meter, dan lebar ruas tersebut masih memenuhi standar minimal jalur sirkulasi sebesar 1.5 meter. Hal ini membantu mengatasi permasalahan jalur sirkulasi parkir sepeda motor yang sempit. Pemetaan satuan ruang parkir dengan sudut pola parkir $30^{\circ}, 45^{\circ}, 60^{\circ}$ dan $90^{\circ}$, membantu mengatasi permasalahan penataan parkir yang kurang tertib, pengaturan beberapa sepeda motor tidak teratur. Rancangan sudut pola parkir $45^{\circ}$ memiliki lebar satuan ruang parkir 0.75 meter. Lebar satuan ruang parkir 0.75 meter mengurangi kekhawatiran pengguna atas terjadinya sepeda motor rubuh dan helm terjatuh. Rancangan sudut pola parkir $30^{\circ}, 45^{\circ}, 60^{\circ}$ dan $90^{\circ}$, pada bentuk parkir sektor 3 , memiliki daya tampung maksimal 536 ruang satuan parkir.

\section{Perancangan Desain Pola Parkir Sektor 4}

Setiap sektor pada fasilitas parkir sepeda motor FT UNS memiliki dimensi dan bentuk yang berbeda. Pada Gambar 5.24, 4.25, 4.26, 4.27 akan ditunjukkan beberapa desain pola parkir dengan berbagai sudut yang sesuai dengan keadaan dari fasilitas parkir sepeda motor FT UNS pada sektor 4. Desain tersebut juga disertai dengan arah sirkulasi parkir sebagai dasar perancangan arah sudut pola parkir. Dari beberapa desain pola parkir tersebut akan didapatkan desain pola parkir yang paling optimal untuk keadaan fasilitas parkir sepeda motor FT UNS sektor 4.

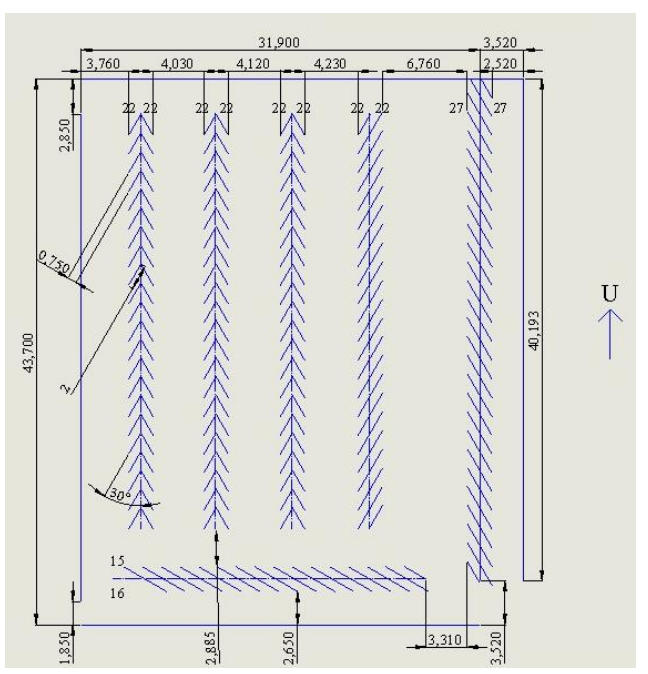

(a)

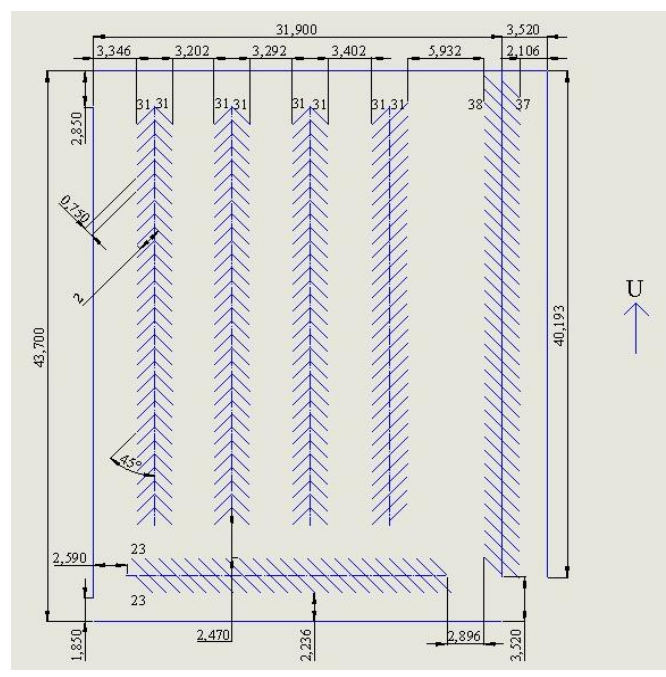

(b) 


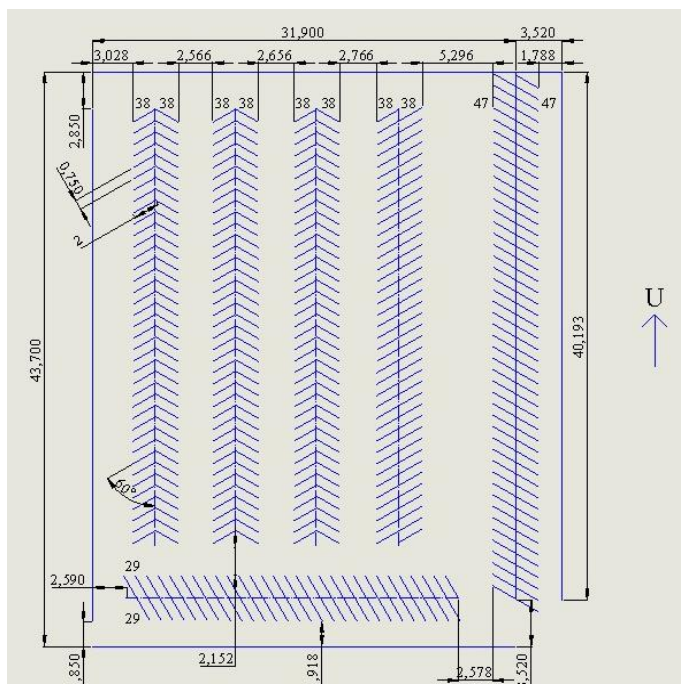

(c)

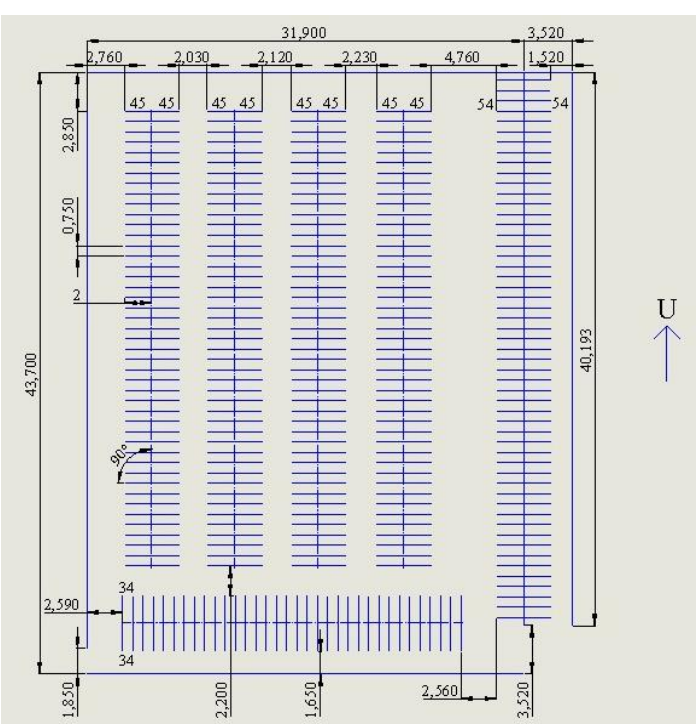

(d)

Gambar 4. Desain Pola Parkir Fasilitas Parkir FT UNS Sektor 4 menggunakan pola parkir dengan sudut (a) $30^{\circ}$, (b) $45^{\circ}$, (c) $60^{\circ}$ dan (d) $90^{\circ}$ (dalam meter)

Pada sudut pola parkir (a) $30^{\circ}$, (b) $45^{\circ}$, (c) $60^{\circ}$ dan (d) $90^{\circ}$ posisi parkir sepeda motor tidak mengganggu luas jalan sirkulasi masuk sepeda motor, yakni lebih dari 1.5 meter, dan lebar ruas tersebut masih memenuhi standar minimal jalur sirkulasi sebesar 1.5 meter. Hal ini membantu mengatasi permasalahan jalur sirkulasi parkir sepeda motor yang sempit. Pemetaan satuan ruang parkir dengan sudut pola parkir $30^{\circ}, 45^{\circ}, 60^{\circ}$ dan $90^{\circ}$, membantu mengatasi permasalahan penataan parkir yang kurang tertib, pengaturan beberapa sepeda motor tidak teratur. Rancangan sudut pola parkir $45^{\circ}$ memiliki lebar satuan ruang parkir 0.75 meter. Lebar satuan ruang parkir 0.75 meter mengurangi kekhawatiran pengguna atas terjadinya sepeda motor rubuh dan helm terjatuh. Rancangan sudut pola parkir $30^{\circ}, 45^{\circ}, 60^{\circ}$ dan $90^{\circ}$, pada bentuk parkir sektor 4, memiliki daya tampung maksimal 176 ruang satuan parkir.

\section{Perancangan Desain Pola Parkir Sektor 5}

Setiap sektor pada fasilitas parkir sepeda motor FT UNS memiliki dimensi dan bentuk yang berbeda. Pada Gambar 5.28, 4.29, 4.30, 4.31 akan ditunjukkan beberapa desain pola parkir dengan berbagai sudut yang sesuai dengan keadaan dari fasilitas parkir sepeda motor FT UNS pada sektor 5. Desain tersebut juga disertai dengan arah sirkulasi parkir sebagai dasar perancangan arah sudut pola parkir. Dari beberapa desain pola parkir tersebut akan didapatkan desain pola parkir yang paling optimal untuk keadaan fasilitas parkir sepeda motor FT UNS sektor 5.

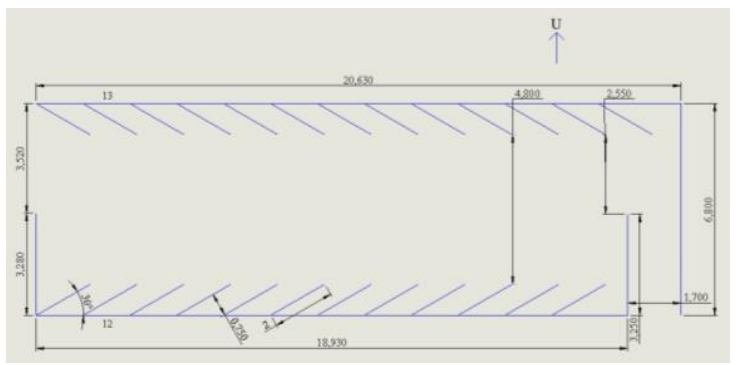

(a)

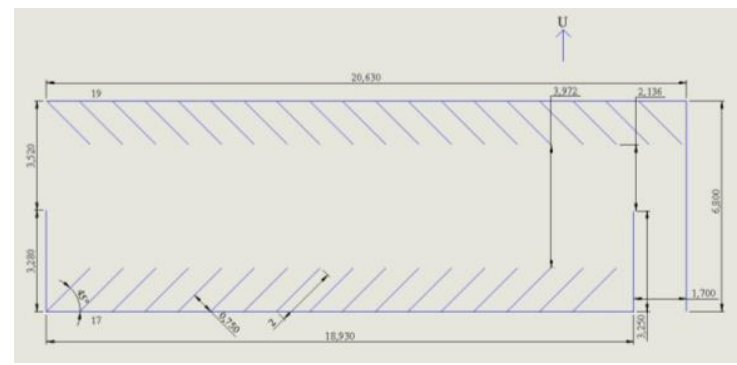

(b) 


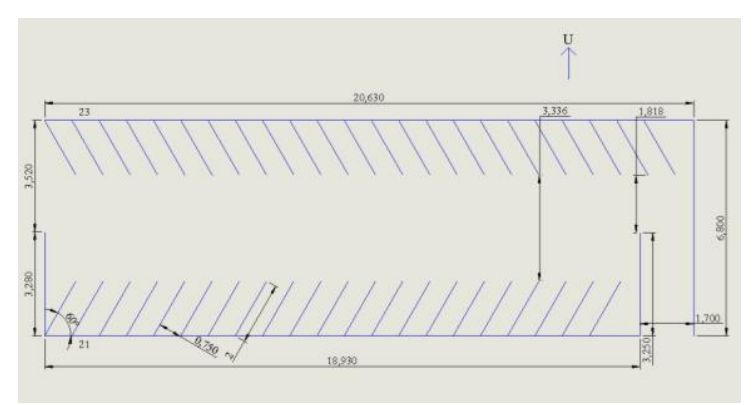

(c)

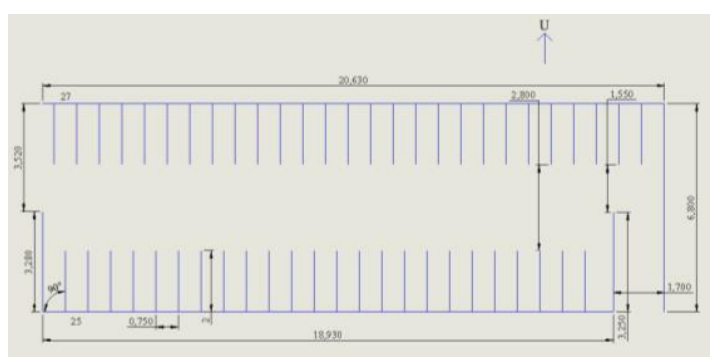

(d)

Gambar 5. Desain Pola Parkir Fasilitas Parkir FT UNS Sektor 5 menggunakan pola parkir dengan sudut (a) $30^{\circ}$, (b) $45^{\circ}$, (c) $60^{\circ}$ dan (d) $90^{\circ}$ (dalam meter)

Pada sudut pola parkir (a) $30^{\circ}$, (b) $45^{\circ}$, (c) $60^{\circ}$ dan (d) $90^{\circ}$, posisi parkir sepeda motor tidak mengganggu luas jalan sirkulasi masuk sepeda motor, yakni lebih dari 1.5 meter, dan lebar ruas tersebut masih memenuhi standar minimal jalur sirkulasi sebesar 1.5 meter. Hal ini membantu mengatasi permasalahan jalur sirkulasi parkir sepeda motor yang sempit. Pemetaan satuan ruang parkir dengan sudut pola parkir $30^{\circ}, 45^{\circ}, 60^{\circ}$ dan $90^{\circ}$, membantu mengatasi permasalahan penataan parkir yang kurang tertib, pengaturan beberapa sepeda motor tidak teratur. Rancangan sudut pola parkir $30^{\circ}, 45^{\circ}, 60^{\circ}$ dan $90^{\circ}$ memiliki lebar satuan ruang parkir 0.75 meter. Lebar satuan ruang parkir 0.75 meter mengurangi kekhawatiran pengguna atas terjadinya sepeda motor rubuh dan helm terjatuh. Rancangan sudut pola parkir $30^{\circ}, 45^{\circ}, 60^{\circ}$ dan $90^{\circ}$, pada bentuk parkir sektor 5 , memiliki daya tampung maksimal 52 ruang satuan parkir.

\section{Perhitungan Kapasitas Maksimal dari Desain Pola Parkir}

Tabel 1 menunjukkan alternatif-alternatif sudut pada desain pola parkir yang dapat digunakan pada tiap sektor pada fasilitas parkir sepeda motor FT UNS. Desain pola parkir yang dipilih adalah desain pola parkir yang dapat menampung jumlah petak parkir paling banyak.

Tabel 1. Jumlah Petak Parkir Pada Setiap Sektor

\begin{tabular}{|l|l|l|l|l|}
\hline \multirow{2}{*}{ Lokasi Parkir } & \multicolumn{4}{|c|}{ Sudut } \\
\cline { 2 - 5 } & $30^{\circ}$ & $45^{\circ}$ & $60^{\circ}$ & $90^{\circ}$ \\
\hline Sektor 1 & 97 & 137 & 128 & $\mathbf{1 5 1}$ \\
\hline Sektor 2 & 63 & 88 & 111 & $\mathbf{1 3 1}$ \\
\hline Sektor 3 & 84 & 118 & 148 & $\mathbf{1 7 6}$ \\
\hline Sektor 4 & 261 & 369 & 456 & $\mathbf{5 3 6}$ \\
\hline Sektor 5 & 25 & 36 & 44 & $\mathbf{5 2}$ \\
\hline
\end{tabular}

Jumlah petak parkir optimal untuk tiap sektor pada fasilitas parkir FT UNS yaitu: sektor 1 dengan sudut $90^{\circ}$ dengan daya tampung sebesar 151 sepeda motor, sektor 2 dengan sudut $90^{\circ}$ dengan daya tampung sebesar 131 sepeda motor, sektor 3 dengan sudut $90^{\circ}$ dengan daya tampung sebesar 176 sepeda motor, sektor 4 dengan sudut $90^{\circ}$ dengan daya tampung sebesar 536 sepeda motor, dan sektor 5 dengan sudut $90^{\circ}$ dengan daya tampung sebesar 52 sepeda motor. Total kapasitas kendaraan sepeda motor untuk desain pola parkir pada fasilitas parkir sepeda motor FT UNS apabila menggunakan sudut parkir yang paling optimum yaitu sudut $90^{\circ}$ untuk semua sektor parkir, sebesar 1046 sepeda motor.

Desain pola parkir dengan sudut $90^{\circ}$ mampu menyelesaikan permasalahan yang ada di tempat parkir FT UNS. Pola parkir dengan sudut $90^{\circ}$ memiliki beberapa keuntungan sebagai berikut: posisi parkir sepeda motor tidak mengganggu luas jalan sirkulasi masuk sepeda motor, yakni lebih dari 1.5 meter, dan lebar ruas tersebut masih memenuhi standar minimal jalur 
sirkulasi sebesar 1.5 meter. Hal ini membantu mengatasi permasalahan jalur sirkulasi parkir sepeda motor yang sempit. Pemetaan satuan ruang parkir dengan sudut pola parkir $90^{\circ}$, membantu mengatasi permasalahan penataan parkir yang kurang tertib, pengaturan beberapa sepeda motor tidak teratur. Rancangan sudut pola parkir $90^{\circ}$ memiliki lebar satuan ruang parkir 0.75 meter. Lebar satuan ruang parkir 0.75 meter mengurangi kekhawatiran pengguna atas terjadinya sepeda motor rubuh dan helm terjatuh. Rancangan sudut pola parkir $90^{\circ}$, pada bentuk parkir di semua sektor, memiliki daya tampung lebih banyak dibandingkan sudut pola parkir $30^{\circ}, 45^{\circ}$, dan $60^{\circ}$.

\section{KESIMPULAN}

Desain pola parkir dengan sudut $90^{\circ}$ merupakan desain pola parkir yang optimal. Jumlah sepeda motor yang mampu ditampung sebanyak 1046 sepeda motor. Metode ergonomi partisipatori mampu menyelesaikan permasalahan di tempat parkir FT.UNS. Perancangan pola parkir ke depannya harus mempertimbangkan aspek aksesibilitas kepada kaum difabel.

\section{DAFTAR PUSTAKA}

Aziz, M.A. (2011). Perancangan Ulang Tempat Kerja Operator Dengan Pendekatan Ergonomi Partisipatori Untuk Mengurangi Keluhan Muskuloskeletal dan Kelelahan (Tugas Akhir Sarjana, Universitas Islam Indonesia). Yogyakarta.

Cole, D., Rivilis, I., Van Eerd, D., Cullen, K., Irvin, E., Kramer, D., (2005), Effectiveness of participatory ergonomic interventions: A systematic reviewe, Toronto: Institute for Work \& Health.

de Jong, A.M.s \& Vink, P., (2002), Participatory ergonomics applied in installation work, Applied Ergonomics,33, 439-448.

Direktur Jendral Perhubungan Darat. (1996). Keputusan Direktur Jenderal Perhubungan Darat tentang Pedoman Teknis Penyelenggaraan Fasilitas Parkir. Jakarta: Departemen Perhubungan.

Mahardin, Dinta. (2005). Perancangan Pola Parkir di Areal Utama Pasar Klewer Surakarta (Tugas Akhir Sarjana, Universitas Sebelas Maret Surakarta). Surakarta. 